\title{
O relacjach byłych więźniów \\ kacetów w kontekście czasu, miejsca i sytuacji ich powstania \\ (albo o pożytkach z historii mówionej) ${ }^{1}$
}

Wroctawski Rocznik Historii Mówionej Rocznik II, 2012

O tym, że ludzka pamięć jest „zawodna”, „niepełna”, „fragmentaryczna” przekonuje nas codzienne doświadczenie. Przekonuje zapewne także historyków. Może dlatego - między innymi dlatego - wielu z nich z nieufnością, jeśli nie podejrzliwością, traktuje źródła historyczne ufundowane na pamięci. Szukają bowiem - najczęściej, bo nie zawsze - odpowiedzi na pytanie o to, "jak było naprawdę", a mniej (lub wcale) interesuje ich to, co ludzie pamiętają i opowiadają, że było. Chyba że zajmują się historią świadomości albo mentalności. Ale i wtedy wolą raczej opisywać to, co ludzie kiedyś myśleli, w inny sposób niż opierając się na tym, co dziś myślą, że wtedy myśleli.

Czasem jednak, gdy innych, pewniejszych, bardziej godnych wiary źródeł brakuje, trzeba sięgać do pamięci uczestników, obserwatorów, aktorów... nie bardzo (dla historyka) odległych wydarzeń. Gdy tymi wydarzeniami są zbrodnie minionego stulecia, odwołanie do pamięci ofiar

1 Praca naukowa finansowana w ramach Programu Ministra Nauki i Szkolnictwa Wyższego pod nazwą „Narodowy Program Rozwoju Humanistyki w latach 2011-2013". 
jest - przynajmniej bywa - szczególnym obowiązkiem etycznym. A ta ich pamięć zyskuje status „świadectwa”.

Nieco inaczej problematyka pamięci przedstawia się tym badaczom, niekoniecznie historykom, którzy na co dzień obcują z relacjami „świadków historii" - ze źródłami historii mówionej - i dla których te relacje są sposobem opowiadania o przeszłości. Najczęściej zresztą nie tylko je analizują, ale także sami „wywołują” i rejestrują. Dla nich (dla nas) ludzka pamięć - i niepamięć - jest po prostu obszarem badawczym. Bywa że fascynującym. To nie znaczy, iż zajmujemy się tylko pamięcią, a już nie tym, co jest pamiętane. Znaczy natomiast, że w polu widzenia mamy stale - albo mieć powinniśmy - zapośredniczenie przeszłych ludzkich doświadczeń przez filtry pamięci (niepamięci) i narracji (albo niemożności jej zbudowania).

Chciałbym tutaj zatrzymać się na chwilę przy tych właśnie zapośredniczeniach, tych filtrach, analizując pewien zespół źródeł - relacje złożone przez byłych więźniów hitlerowskich obozów koncentracyjnych. Ta analiza opierać się będzie nie na więźniarskich relacjach w ogóle, lecz na bardzo konkretnych ich przykładach. Będę porównywał biograficzne wywiady narracyjne byłych więźniów kacetów, zarejestrowane w ramach międzynarodowego projektu dokumentacyjnego Mauthausen Survivors Documentation Project (MSDP) z tak zwanymi oświadczeniami byłych więźniów zbieranymi przez Muzeum Auschwitz. Mniej chodzi mi przy tym o teoretyczne porównanie obu rodzajów źródeł - choć i tym się przy okazji zajmuję - co o uważne przyjrzenie się wypowiedziom tych samych osób, byłych więźniów Auschwitz i Mauthausen, którzy przebywali w obu tych obozach, złożyli kiedyś (zwykle wiele lat temu) „oświadczenie” dla Muzeum Auschwitz, a przed kilkoma laty udzielili wywiadów w ramach wspomnianego projektu dotyczącego Mauthausen.

\section{Mauthausen Survivors Documentation Project (MSDP)}

Ten mój wybór nie jest przypadkowy. Pracując w Ośrodku KARTA, sam byłem zaangażowany w prowadzenie wywiadów w ramach Mauthausen Survivors Documentation Project. Był to największy projekt historii mówionej (oral history) realizowany w ostatnich latach w Europie, w którym 
nagrywano relacje biograficzne byłych więźniów jednego kompleksu obozów koncentracyjnych - Mauthausen i jego kilkudziesięciu podobozów. Realizowany był w latach 2002-2003 i zarejetrowano w nim ponad 850 wywiadów, z czego ponad 10\% na wideo, w ponad dwudziestu krajach Europy, Ameryki Północnej i Południowej oraz w Izraelu. Inicjatotorem i sponsorem przedsięwzięcia było Ministerstwo Spraw Wewnętrznych Republiki Austrii, kierownikiem naukowym profesor Gerhard Botz z Instytutu Historii Najnowszej Uniwersytetu Wiedeńskiego, a koordynatorem całości Instytut Badania Konfliktu w Wiedniu.

Po zakończeniu projektu wszystkie wywiady zostały opracowane i zarchiwizowane w Archiwum Mauthausen należącym do Ministerstwa Spraw Wewnętrznych i są sukcesywnie udostępniane do celów badawczych. Fragmenty wybranych 20 wywiadów wideo - po jednym z każdego kraju - stały się częścią nowej ekspozycji w Miejscu Pamięci Mauthausen, na terenie byłego obozu.

Realizatorem polskiej części projektu był warszawski Ośrodek KARTA. To była sytuacja dosyć wyjątkowa, gdyż niemal we wszystkich pozostałych krajach realizację projektu powierzono instytutom naukowym, zwykle uniwersyteckim - najczęściej historii najnowszej albo socjologii. My w Polsce zebraliśmy 164 relacje byłych polskich więźniów kompleksu obozowego Mauthausen i była to największa liczba wywiadów zrealizowana w jednym kraju. Miała w jakiś sposób odzwierciedlać „narodowościowe proporcje” wewnątrz społeczności więźniarskiej. Polacy stanowili bowiem największą grupę więźniów tego systemu obozów - niemal co czwarty z około dwustu tysięcy uwięzionych pochodził z Polski.

MSDP był - zgodnie ze swoją nazwą - projektem dokumentacyjnym, a nie badawczym (ten ostatni, w którym przedmiotem badań są zebrane wówczas relacje, rozpoczął się rok temu także na Uniwersytecie Wiedeńskim). To znaczy, że nagrywano relacje tylko po to, by je utrwalić, wstępnie opracować, zarchiwizować i udostępnić do dalszych badań. Jakich badań? - Potencjalnie wielu i różnorodnych. Bardziej precyzyjnej odpowiedzi nie próbowano udzielać, by nadmiernie nie determinować procesu dokumentacji. A raczej - by tak zbudować jego ramy, aby zebrany materiał służyć mógł różnym badaniom, by dało się wobec niego stawiać rozmaite pytania.

Dlatego też, i zgodnie z niemiecką tradycją badań biograficznych, za obowiązującą metodę dokumentacyjną przyjęto w projekcie biograficzny wywiad narracyjny. Że taki wybór jest tutaj najlepszy, podpowiadało 
także doświadczenie badawcze Paula Thompsona ${ }^{2}$. Nie był też niczym wyjątkowym - ten sposób dokumentacji stał się przecież standardem wielu projektów historii mówionej. W modelowym wariancie relacje zebrane w projekcie składać się miały z kilku części czy faz:

1) Life story - swobodna narracja biograficzna inicjowana otwartą prośbą osoby prowadzącej wywiad o opowiedzenie historii życia. Rozmówca mógł zbudować swoją autobiograficzną opowieść na swój własny sposób, własnymi kategoriami, w swoim stylu narracyjnym - bez żadnych ingerencji nagrywającego. Rolą tego ostatniego miało być tylko (a raczej "tylko", bo to nie zawsze tak proste) uważne słuchanie i stymulowanie tej opowieści, czasem jej delikatne „popchnięcie”. Celem tej najważniejszej części wywiadu była bowiem aktywizacja pamięci, wywołanie z niej poprzez narrację - możliwie wielu obrazów o przeszłości (bo nie „z przeszłości”). Ta pierwsza część mogła trwać od kilkunastu, a nawet kilku minut - gdy rozmówca „nie miał nic do powiedzenia” - do kilku godzin.

2) Gdy swobodna opowieść narratora dobiegła końca - a zwykle znak tego końca był wyraźny z jego/jej strony - nagrywający mógł od razu zareagować na konkretne fragmenty wysłuchanej historii. Na tematy, zdarzenia, nazwy, nazwiska, daty - prosząc o ich wyjaśnienie, doprecyzowanie. Gdy jednak swobodna narracja trwała długo i była „gęsta”, taka bezpośrednia reakcja na konkretne jej passusy musiała być niezwykle wybiórcza. W praktyce też często z niej rezygnowaliśmy (my - nagrywający), przechodząc od razu - albo lepiej następnego dnia lub za kilka dni, gdy taka przerwa była możliwa - do następnej fazy wywiadu.

3) Ta następna część to pytania otwarte - dopytywanie o tematy, zdarzenia, a przede wszystkim doświadczenia pominięte w pierwszej części relacji albo takie, które zostały już opowiedziane, ale w przekonaniu prowadzącego rozmowę mogły i powinny zostać rozwinięte i pogłębione. Osoby nagrywające relacje otrzymały nawet zestaw tematów, które mogły stanowić podstawę do formułowania otwartych pytań. W przeważającej części dotyczyły one doświadczenia obozowego - cały projekt był przecież poświęcony obozom kompleksu Mauthausen i pamięci o nim jego byłych więźniów. Ale ten zestaw tematów nie miał być - i przez nas nigdy

2 Paul Thompson Life Story Interview with Karen Worcman, June 1996, http://www. esds.ac.uk/qualidata/online/data/edwardians/biography/PaulThompsonLifeStoryInterview1996.pdf (dostęp: 17 XI 2011 r.). 
nie był - traktowany jako zestaw pytań, które należało zadać. Podręcznik projektu stawiał to jasno: „Należy pytać w taki sposób, by pobudzać opowieści i epizody, by pozwalać rozmówcy opisywać postaci, rodzinę, przyjaciół albo prześladowców, by zachęcać do opowiadania o codziennych praktykach, o poranku, w którym rozpoczęła się deportacja, o przybyciu do obozu... Z tych konkretnych historii dowiemy się więcej o osobistych postawach naszych rozmówców w tamtym momencie, niż gdybyśmy pytali o nie wprost"3. W praktyce ta część relacji była często powtórną tym razem wspólną - pracą nad całą opowieścią autobiograficzną.

4) W ostatniej, opcjonalnej, części wywiadu można było poprosić rozmówcę o podsumowanie, dodatkową interpretację swojego doświadczenia obozowego albo jego przetrwania. Chodziło o puentę, a nie o „zwykłe” interpretacje doświadczeń i „filozofie” ocalenia wbudowane w tok opowieści, zintegrowane w pamięci z konkretnym doświadczeniem. Tu na końcu było też miejsce na ewentualną krytykę czy polemikę z nagrywanym. W praktyce naszego nagrywania ten ostatni element prawie się nie pojawiał.

Realizując Mauthausen Survivors Documentation Project - spotykając się i rozmawiając z byłymi więźniami tego systemu obozów - staraliśmy się przede wszystkim wytwarzać taką przestrzeń komunikacyjną, by nasi rozmówcy mogli i chcieli mówić otwarcie i swobodnie o swoich obozowych (ale także przed- i poobozowych) doświadczeniach. Podział na te wyżej zarysowane fazy miał przede wszystkim temu pomagać - a w żadnym razie nie ograniczać tej swobody. Na ile każdy z nas potrafił - w projekcie uczestniczył wieloosobowy zespół, a w nim zapewne każdy nieco inaczej prowadził nagrania - staraliśmy się nie indagować nagrywanych osób wieloma szczegółowymi, faktograficznymi pytaniami, ale raczej pozwalać się prowadzić ich opowieściom, podążać za nimi.

W tym projekcie zebraliśmy więc nie „po prostu” relacje byłych więźniów Mauthausen na temat ich pobytu w tym obozie, ale - mimo ich dużej różnorodności - ich szczególny rodzaj: biograficzne i narracyjne wywiady historii mówionej. Wytworzyliśmy, czy raczej wywołaliśmy, pewien typ historycznych źródeł. A przy okazji wiele ponadto, bo powstał wielki materiał badawczy dla psychologów, socjologów, językoznawców...

3 A. v. Plato, Some Remarks on the Interviews, [w:] MSDP. Manual for Interviews, Vienna 2002, maszynopis niepublikowany, s. 11. 


\section{Relacje MSDP a „oświadczenia”}

Zdecydowana większość naszych rozmówców, byłych więźniów Mauthausen, po raz pierwszy relacjonowała swoją historię w taki sposób. Wielu, jeśli nie wszyscy, oczywiście opowiadało wcześniej niejeden raz o swoich różnych doświadczeniach obozowych, ale te dotychczasowe opowieści były zwykle zupełnie fragmentaryczne, epizodyczne, nie zebrane w żadną „pełną” narrację biograficzną, nawet nie zestawione obok siebie. Jeszcze rzadziej były dokumentowane (nagrywane) z zamiarem ich opracowania, archiwizacji i udostępnienia do późniejszego użycia. Na takich „surowych” opowieściach szczególnie nam zresztą zależało. Realizując ten projekt, woleliśmy raczej stwarzać „świadków historii” - to znaczy rozmawiać z ludźmi, którzy nimi dotąd nie byli - niż słuchać już znanych, gotowych i zamkniętych opowieści. Dlatego zdecydowana większość ze 164 relacji „Mauthausenowców”, jakie zebraliśmy w tym projekcie, to jedyne istniejące zapisy pamięci i doświadczeń naszych rozmówców. Jednak nie wszystkie. Ważny wyjątek stanowią „oświadczenia” zgromadzone w Archiwum Państwowego Muzeum Auschwitz-Birkenau.

Mauthausen (albo któryś z jego podobozów: Gusen, Ebensee) był dla większości polskich więźniów tego kacetu jednym z etapów, najczęściej ostatnim, ich obozowej drogi - tu stracili życie albo doczekali wyzwolenia. Wielu więziono wcześniej w Auschwitz. Dlatego prawie jedna czwarta nagranych przez nas ocalonych z Mauthausen była jednocześnie ocalonymi z Auschwitz. Dziesięciu z tej grupy złożyło też swoje „oświadczenia” dla Muzeum w Auschwitz. Najstarsze z tych „oświadczeń” zostało zarchiwizowane w Muzeum w latach 6o. ubiegłego wieku, najnowsze, zarejestrowane na taśmie wideo, powstało $\mathrm{w}$ roku 2004 - rok po relacji nagranej w ramach MSDP.

Dzięki uprzejmości Muzeum mogliśmy wymienić się zapisami tych świadectw - otrzymaliśmy kopie tych dziesięciu „oświadczeń”, a przekazaliśmy kopie dziesięciu wywiadów nagranych w naszym projekcie z tymi samymi więźniami. To pozwoliło mi na porównanie nie tylko konkretnych relacji tych samych osób, zarejestrowanych w innym miejscu, w innym czasie, w innych okolicznościach, lecz także porównać oba rodzaje tych źródeł - na pierwszy rzut oka bardzo podobnych. Jedne i drugie są wywołane, opierają się na pamięci, są narracyjne. Mam jednak świadomość, że to drugie, rodzajowe porównanie obu grup źródeł, opiera się na ryzykownym uogólnieniu - opartym na bardzo małej i z pewnością niereprezentatywnej próbie. Ostrożnie je tu jednak proponuję, bo w tych 
dziesięciu „oświadczeniach” i - pomyśleć można odpowiadającym im re-

lacjach biograficznych, daje się chyba rozpoznać kilka ich ważnych cech charakterystycznych.

Takie porównania relacji tych samych osób, zarejestrowanych w różnych momentach ich życia, w różnych okolicznościach i przez różne (a czasem te same) osoby lub instytucje - a dotyczących tych samych (?), odległych i, wydawałoby się, dawno „zamkniętych” doświadczeń z ich życia - to pomysł w historii mówionej czy badaniach biograficznych nienowy. Dla mnie najważniejszą inspiracją do tego typu analiz były prace Michaela Pollacka, Friedhelma Bolla, a ostatnio Dori'ego Lauba z Fortunoff Video Archive ${ }^{4}$.

Ciekawiło mnie w szczególności to, czy i w jaki sposób różne procedury badawcze, różne metody wywoływania relacji „świadków historii”, różne techniki gromadzenia (i konstruowania) danych, wpływają na treść i formę ich opowieści. Jak definiują obie sytuacje „składania świadectwa” uczestnicy każdego z tych spotkań - człowiek opowiadający swoją historię i drugi, który jej słucha i ją zapisuje. Jak ta definicja zmienia narrację. Czy narracyjne wywiady biograficzne nagrywane z byłymi więźniami kacetów po tylu latach - około sześćdziesięciu - od wydarzeń, których przede wszystkim dotyczą, dostarczają nam jakiejś nowej wiedzy w porównaniu z wcześniejszymi relacjami tych samych osób. A jeśli tak - co to za wiedza: czy są to „nowe” fakty, czy raczej inne interpretacje faktów znanych?

Pytałem także - abstrahując trochę od metodologii - jak zmienia się w czasie i w zależności od różnych kontekstów (a raczej, jak może się zmieniać) opowieść biograficzna „świadka historii”. Wreszcie: jaki wpływ, jeśli jakikolwiek, na treść narracji biograficznych byłych polskich więźniów kacetów, ma tak odległy, ale wydaje się istotny, czynnik, jak radykalna zmiana społeczno-polityczna roku 1989/9o i związana z nią reinterpretacja przeszłości? Także tych jej elementów, które należą do bezpośredniego doświadczenia narratorów. A odwołując się do konceptu Halbawachsa: czy i jak zmiana społecznych ram pamięci daje się rozpoznać w czymś tak

4 M. Pollack, Die Grenzen des Sagbaren. Lebensgeschichte von KZ-Überlebenden als Augenzeugenberichte und als Identitätsarbeit, Frankfurt am Main-New York 1988; F. Boll, Sprechen als Last und Befreiung. Holocaust-Überlebende und politisch Verfolgte zweier Diktaturen. Ein Beitrag zur deutsch-deutschen Erinnerungskultur, Bonn 2003; D. Laub, J. Bodenstab, Revisiting Testimonies of Holocaust Survivors, [w:] Hitler's Slaves. Life Stories of Labourers in Nazi-Occupied Europe, New York-Oxford 2010, s. 426-440. 
indywidualnym i na pozór „aspołecznym”, jak indywidualna, jednostkowa pamięć szczegółowych zdarzeń z własnej biografii?

Aby na postawione wyżej pytania próbować odpowiadać, trzeba coś wiedzieć o praktykach wytwarzania źródeł - relacji/oświadczeń - które za chwilę chcę tu porównawczo analizować. O biograficznych, narracyjnych, częściowo strukturyzowanych, najczęściej dwuczęściowych (swobodna narracja i pytania otwarte), relacjach nagrywanych w ramach MSDP była powyżej mowa. Pora powiedzieć kilka słów o „oświadczeniach” oświęcimskich.

Ich charakterystyka nie jest tak prosta, jak się może wydawać. Podstawą "oświadczeń" oświęcimskich są wywiady z byłymi więźniami tego obozu (Auschwitz i Birkenau), prowadzone przez pracowników Państwowego Muzeum Auschwitz-Birkenau w Oświęcimiu. Te wywiady zbierano niemal od początku istnienia Muzeum i zbiera się je do dziś. Nie wszystkie jednak rejestrowano w formie dźwiękowej czy - tym bardziej - na taśmie wideo. Ale nawet, gdy to robiono, ostatecznym produktem - a dla historyka źródłem - pozostaje tutaj zredagowany tekst. Tym samym już poprzez sposób traktowania zapisu audio i wideo Muzeum kładzie nacisk na treść relacji. A znając te zredagowane transkrypcje, dodać można: na faktograficzną ich treść. Zbiór tych zredagowanych tekstów, nazwanych „oświadczeniami”, należy dziś do jednego z ważniejszych w całym Archiwum. Jest to zbiór ogromny - zawiera ponad trzy tysiące relacji/„oświadczeń” (obie nazwy funkcjonują obok siebie) w ponad około 150 tomach ${ }^{5}$.

Uważna lektura dziesięciu jednostek archiwalnych, dziesięciu relacji z tego zbioru, które analizowałem, daje obraz dużej różnorodności. Trudno odnaleźć jakąś jedną regułę czy metodę badawczą stojącą za tymi relacjami. Zapewne jej nie ma - to nie zarzut, bo przecież być nie musi. Chodzi po prostu o dowiedzenie się jak najwięcej o historii obozu. Ale i tutaj, co dobrze widać po tej małej próbce, wiele zależy od osoby prowadzącej rozmowę (przetworzoną potem na oświadczenie/relację), od jej/jego szczególnych zainteresowań i pytań. A także, co z poprzednim ściśle zwykle powiązane, od instytucji, dla której zbierane są te relacje. Także od bieżącego jej interesu - nawet, gdy chodzi o „interes” dokumentacyjno-badawczy.

5 Ten zbiór należy do zasobu Archiwum Państwowego Muzeum Auschwitz-Birkenau mieszczącego się na terenie byłego obozu i jest dostępny na ogólnych zasadach korzystania z tego Archiwum: http://pl.auschwitz.org/m/index.php?option=com content\&task=view\&id=964\&Itemid=132 (dostęp: 17 XI 2011 r.). 
W tej różnorodności dziesięciu relacji z Muzeum Auschwitz-Birkenau odnajduję jednak kilka rysów charakterystycznych. Stają się one dla mnie zapewne wyraźniejsze przez to, że - siłą rzeczy, a raczej własnego doświadczenia - konfrontuję je z relacjami nagrywanymi w projekcie MSDP. Nie jestem więc obiektywny w tych porównaniach, bo na jeden zbiór źródeł - ten oświęcimski - patrzę z zewnątrz, na drugi - ten powstały w projekcie dotyczącym ocalonych z Mauthausen - ze środka. Przez takie "skrzywienie” coś zapewne z pola widzenia tracę, ale może w zamian coś innego dostrzegam.

Relacje zbierane przez Muzeum - osiem na dziesięć - zostały zarejstrowane (albo tylko wysłuchane i zapisane bez nagrywania) na terenie Muzeum, przy okazji odwiedzin tego miejsca przez byłych więźniów. Takie odwiedziny nie są dla ocalonych sytuacją codzienną. Nie jest też taką sytuacją pobyt na terenie dawnego obozu. Oczywiście poza wyjątkami dotyczącymi byłych więźniów należących do nielicznej grupy zupełnie zadomowionych w Muzeum, oswojonych z po- i postobozową przestrzenią. Ale dla tych ostatnich - w przeciwieństwie do dominującej większości pozostałych - na ogół nie ma już znaczenia komu, gdzie i po raz który opowiadają swoją obozową historię (i historię obozu zarazem). Wywiady w ramach MSDP, z kilkoma zaledwie wyjątkami, powstawały w domach rozmówców. I choć sytuacja takiego wywiadu była dla nagrywanych także wyjątkowa, to już niekoniecznie była oficjalna. Całe zdarzenie rozgrywało się w oswojonej przestrzeni własnego mieszkania. To mogło istotnie zmienić definicję sytuacji wywiadu przez rozmówców, ale też przez nagrywających. Rozmowa w Muzeum sprzyjała poczuciu uczestnictwa w składaniu „świadectwa” - dokumentu. Rozmowa w naszym projekcie dokumentacyjnym kojarzyć się raczej mogła ze wspominaniem. Zatem miejsce powstania, wywołania obu tych źródeł zdecydowanie odróżnia oba zbiory relacji. Nie znaczy to, rzecz jasna, że każda relacja z jednego albo drugiego zbioru w taki właśnie sposób zdeterminowana jest miejscem - chodzi tylko o uchwycenie dominującej tendencji i zwrócenie uwagi na nieobojętność kontekstu sytuacyjnego.

Większy formalizm „oświadczeń” nie dotyczy tylko sytuacji, w jakiej powstały. Przejawia się też w ich, by tak rzec, efekcie końcowym. „Oświadczenia” oświęcimskie są spisane, zredagowane, ostemplowane pieczęcią Muzeum (każda strona oddzielnie) i na końcu podpisane przez obie strony - składającego oraz zapisującego relację. Gdy bierze się je do ręki, wydaje się, że oto trzyma oficjalny, papierowy dokument. Łatwo z pola uwagi 
znika fakt, że za tym dokumentem skrywa się zawodna pamięć i chwiejna ustna narracja. Tymczasem, gdy słucha się relacji dźwiękowej (tym bardziej, gdy ogląda się zapis wideo), głos (i twarz) rozmówców nie daje nam zapomnieć, że obcujemy z człowiekiem, który konstruuje opowieść o swym doświadczeniu.

Niemałe znaczenie ma także to, że relacje zgromadzone w Muzeum zbierane były przez jego pracowników - zwykle historyków badających historię obozów Auschwitz i Birkenau. Nic dziwnego, że tak wiele pytań zadawanych przez nich byłym wieźniom odnosi się do bardzo konkretnych, nieraz szczegółowych zdarzeń, osób i miejsc ważnych dla historii obozu. W tej faktografii szczególne znaczenie dla zadających pytania wydaje się mieć obozowa topografia - co, gdzie było, jak wyglądało, w jakiej odległości się znajdowało. Drugim centralnym tematem pytań są imiona i nazwiska innych więźniów, a także oprawców, zwłaszcza SS-manów. Relacja miejscami sprawia wrażenie zapisu przesłuchania prokuratorskiego. Indywidualne doświadczenie rozmówcy pozostaje w niej często tylko tłem dla tej faktograficznej precyzji. Zupełnie odwrotnie niż w projekcie MSDP. Tam nagrywającymi bywali także historycy (choć w mniejszości), ale nie badacze historii i topografii Mauthausen.

Miejsce zbierania „oświadczeń”, instytucja, która je zbiera, prowadzący te rozmowy jej pracownicy - to wszystko wzmacnia koncentrację na Auschwitz / Birkenau. O ile droga do obozu - aresztowanie, pobyt w innych więzieniach i obozach, wreszcie transport tutaj - mieszczą się jeszcze w polu zainteresowań pytających i są obecne w tych relacjach, to nie ma tam nic albo jest bardzo niewiele, o późniejszych doświadczeniach rozmówców, o pobycie w innych obozach i wyzwoleniu, o życiu powojennym. Wyjątki to te relacje, w których składający „oświadczenia” nie zostali zatrzymani albo zawróceni do mówienia o Auschwitz przez prowadzącego, a chcieli opowiadać „co było dalej”, po Auschwitz. Ale to - znów odwrotnie niż w wywiadach MSDP - wyjątek od dominującego schematu.

Te wszystkie cechy charakteryzujące, chociaż oczywiście w różnym stopniu, analizowane przeze mnie „oświadczenia” pozwalają na ostrożne uogólnienie. W porównaniu z relacjami nagranymi w ramach MSDP są to źródła znacznie mniej narracyjne, mniej biograficzne, za to w większym stopniu oparte na wymianie typu pytanie-odpowiedź. Nic dziwnego, że mniej w nich swobodnej, niezakłóconej opowieści i że są znacznie krótsze. Czasem kilkakrotnie krótsze od relacji - tych samych osób! - zarejestrowanych w projekcie dokumentacyjnym o Mauthausen. 
Ale, jak powiedziałem, kolekcja relacji oświęcimskich jest bardzo zróżnicowana. Już w tych dziesięciu analizowanych można zaobserwować istotną zmianę. Otóż im relacja złożona wcześniej - a pierwsza tutaj uwzględniona pochodzi z lat 6o. poprzedniego wieku - tym jest bardziej faktograficzna. Im późniejsza - a ostatnia wzięta pod uwagę jest z 2004 roku - tym bardziej swobodna, otwarta, narracyjna. Chociaż nie tak, jak wywiady MSDP. I jednak ciągle mocniej niż one skoncentrowana na faktografii.

To wszystko sprawia wrażenie, że składający swoje „oświadczenia” byli więźniowie Auschwitz definiowani są (i sami siebie tak definiują) jako informatorzy, których zadaniem jest przywołać i zrekonstruować fakty. Tak, jakby ich pamięć była taśmą wideo, z zapisanym w przeszłości filmem (szczególnie w przeszłości obozowej), i główny problem leżał w tym, by ten film odnaleźć, wydobyć z archiwum pamięci i wiernie odtworzyć.

Z kolei wywiady nagrane w ramach Mauthausen Survivors Documentation Project są bardziej - czasem zdecydowanie bardziej - biograficzne, bo obejmują doświadczenia przed- i poobozowe, w tym przed- i powojenne. Są bardziej narracyjne, bardziej zorientowane na doświadczenia, a mniej na fakty - co oznacza, że w większym stopniu obecne są w nich emocje, uczucia, a także interpretacje i „filozofie” przetrwania obozu i życia w ogóle. Nic dziwnego, skoro obejmują także konsekwencje ocalenia - fizyczne, psychologiczne, społeczne...

Wszystkie powyższe rozróżnienia - choć zbudowane na niewielkiej, niereprezentatywnej próbie - zachęcają do sięgnięcia do typologii Michaela Pollacka i scharakteryzowania „oświadczeń” oświęcimskich jako wypowiedzi przed komisją historyczną (Aussagen vor historischen Komissionen / Statements in front of historical commissions), przy czym jedne są bardziej „polityczne”, „quasi-jurydyczne”, inne bardziej „naukowe”, jeszcze inne „osobiste”. Z kolei wywiady Mauthausen Survivors Documentation Project wpisują się znacznie lepiej w typ narracji, nazwanej przez Pollacka opowieścią biograficzną (biografische Erzählungen / biographical narratives) ${ }^{6}$.

Niech te uogólnienia - a więc uproszczenia zarazem - stanowią punkt wyjścia do bardziej szczegółowych porównań. Nie tylko do zestawiania kontrastów, ale też pokazywania podobieństw między oba typami „świadectw”.

6 M. Pollack, op. cit., s. 96-112. 
Tym, co od razu zwraca uwagę, gdy porównuje się relację biograficzną nagraną w ramach Mauthausen Survivors Documentation Project z „oświadczeniem” z Muzeum Auschwitz-Birkenau złożonym przez tę samą osobę - byłego więźnia obu obozów - jest obecność w obu źródłach tych samych faktów. A ściślej - narracja o tych samych przeszłych doświadczeniach. Można powiedzieć, że to zupełnie oczywiste i nie może być inaczej, skoro obie relacje dotyczą tej samej rzeczywistości, obiektywnej, zamkniętej przeszłości. Jednak już chyba mniej oczywiste, że w obu miejscach pojawiają się prawie te same albo po prostu identyczne konstrukcje językowe - te same słowa, zwroty, zdania. Wydaje się, że te konstrukcje są odporne na upływ czasu i wszelkie inne interferencje. A w niektórych przypadkach między relacją złożoną dla Muzeum a tą nagraną dla Mauthausen upłynęło kilkadziesiąt lat.

Obcując z tymi „świadectwami”, widzimy, że doświadczenia raz ujęte w narracyjną formę zostają w niej na zawsze uwięzione. Powstaje narracyjna matryca - jeśli dobrze utrwalona i dość często powielana - służyć może przez wiele lat, pewnie przez całe życie. Przywołanie doświadczeń z własnej biografii oznacza uruchomienie jej po raz kolejny. Odtwarzana jest raczej opowieść, a nie samo doświadczenie. Chociaż narrator nierzadko już tego nie rozdziela. Ta zakrzepła narracja autobiograficzna nie jest bowiem czymś dla niego zewnętrznym. Przeciwnie - zostaje zwykle zintegrowana, uwewnętrzniona, staje się częścią jego tożsamości, jej znakiem charakterystycznym, ważnym elementem autodefinicji. Doświadczenie z przeszłości, z 'tam i wtedy', zamienione zostaje w opowieść o życiu. Ta opowieść bywa nazywana tożsamością narracyjną7.

Ale te trwałe konstrukty narracyjne (fixed narratives) nie są czysto faktograficzne. Nie odnoszą się tylko - jak można by mniemać - do tych zdarzeń z przeszłości, w których pamięć „świadka” zadziała na zasadzie lampy błyskowej8. Otóż ważną część tych utrwalonych narracji stanowią interpretacje i objaśnienia opowiadanych przeszłych doświadczeń. Te in-

7 Pojęcie „tożsamości narracyjnej” nie jest tu nowe. Ma swoje umocowanie filozoficzne - zob. P. Ricoeur, Czas i opowieść, Kraków 2008. Ma też bogatą literaturę psychologiczną - zob. Narracja jako sposób rozumienia świata, red. J. Trzebiński, Gdańsk 2002 .

8 O tym mechanizmie pamięci autobiograficznej i jej konstrukcyjnym charakterze zob.: T. Maruszewski, Pamięć autobiograficzna, Gdańsk 2005, s. 98-106. 
terpretacje i objaśnienia są zintegrowane z samymi doświadczeniami trwale i nierozerwalnie związane z faktografią przeszłości. Razem tworzą nieraz rozbudowane moduły narracyjne.

Sięgnijmy do przykładu. Pan Florian złożył „oświadczenie” dla Muzeum Auschwitz-Birkenau w 1999 r., a trzy lata później relację w projekcie MSDP. W obu narracjach bardzo plastycznie i w obu w bardzo podobny sposób przywołuje pewną obozową "przygodę” z pobytu w Auschwitz. Można ją streścić tak: bohater zasypia w warsztatach i nie zauważa momentu, kiedy jego komando kończy pracę tego dnia i zostaje skierowane z powrotem na blok. Budzi go cisza. Przeżywa strach przed karą za ten występek (a kto zna choć trochę reguły kacetowego świata, wie, że ten strach nie był bezpodstawny). Ale szczęśliwie nic się nie zdarza. Dzięki wysokiej pozycji, jaką zajmuje w hierarchii społeczności więźniarskiej, zwłaszcza dzięki dobrym stosunkom z kapo w tamtym momencie swojej obozowej kariery, zupełnie unika kary. Oto jak interpretuje tamto doświadczenie. W relacji z 1999 r. podsumowuje ten epizod: „Mogę powiedzieć - znowu czuwała nade mną opatrzność”; w relacji z 2002 r.: „Drugi raz opatrzność boska mnie uratowała"10.

Jak widać przywołanie boskiej opatrzności nie musi być spontaniczne. Może być, jak tutaj, częścią utrwalonej i każdorazowo, kiedy potrzeba, powielanej narracji. Metafizyczna, religijna interpretacja zrosła się na stałe z doświadczeniem. Albo po prostu stała się jego integralną częścią.

To jednak tylko jedna „przygoda”, jeden mały epizod rozbudowanej opowieści. I jeden narracyjny konstrukt. Słuchając, czytając i porównując wiele relacji, wyraźnie widzimy, że każda z nich składa się z wielu takich narracyjnych "modułów” - jest układanką złożoną z drobnych elementów. Przy czym te elementy są dosyć autonomiczne - każdy funkcjonować może z powodzeniem jako osobna mikroopowieść, samodzielna historyjka, anegdota. Narrator - a tutaj: były więzień składający relację (czy to dla Muzeum w Auschwitz, czy w projekcie o Mauthausen) - często buduje opowieść z takich gotowych elementów. A że są od siebie dość niezależne, „luźne” - jego zadaniem jest je zlepić, skonstruować z nich

9 Relacja Floriana G. złożona dla Państwowego Muzeum Auschwitz-Birkenau w Oświęcimiu, Kolekcja Oświadczenia t. 144, s. 192.

10 Relacja Floriana G. nagrana w projekcie MSDP, sygnatura w Archiwum Historii Mówionej Ośrodka KARTA:

MSDP_o86; w Archiwum Mauthausen w Wiedniu: OH/ZP1/382. 
możliwie spójną opowieść. Niekiedy - jak w MSDP - „pełną opowieść biograficzną" (full life story). Ta praca konstrukcyjna odbywa się tu na poczekaniu, jest częścią sytuacji wywiadu, składania „świadectwa”. To dynamiczna interakcja, w różnym stopniu, ale jednak otwarte - nawet jeśli jakoś skodyfikowane - zdarzenie komunikacyjne.

Ciekawe jest może to, że sekwencja tych mikroopowieści, tych konstruktów narracyjnych nie jest stała, dana raz na zawsze. To jest układanka, dająca się ułożyć na wiele sposobów, w wiele wzorów. Rozmówcy niejeden raz gubią chronologię, lekce sobie ważą logiczny - jak nam słuchaczom się wydaje - porządek zdarzeń, a mimo to nie mają problemu ze skonstruowaniem z nich dosyć spójnej, całościowej, pełnej narracji. Te same elementy są przywoływane i odtwarzane w różnych konstelacjach. W wywiadzie biograficznym te gotowe konstrukty narracyjne pojawiają się zarówno w pierwszej części - swobodnej opowieści, jak i dalej - w fazie otwartych pytań. Chociaż zdarzają się i tacy „zawodowi opowiadacze”, których cała opowieść jest już utrwalonymi i rutynowo powielanymi konstruktami. Takich jednak nie szukaliśmy.

Zatem sposób wywoływania źródeł nie jest tu decydujący. O ile pozostawimy rozmówcom minimum przestrzeni komunikacyjnej na swobodną narrację o swoich biograficznych doświadczeniach, możemy się spodziewać konstelacji tych, dawno utrwalonych, mikroopowieści. Jeśli jednak zestawem szczegółowych, faktograficznych pytań zredukujemy tę przestrzeń - nie damy szansy pamięci na uruchomienie tych narracyjnych obrazków.

Nim pójdę dalej, chciałbym uczynić jedno zastrzeżenie. Ryzykowne, bo kwestionuje - a na pewno osłabia - cały powyższy wywód, ale chyba konieczne. Nie możemy bowiem wykluczyć, że nasi rozmówcy - byli więźniowie Mauthausen, których nagrywaliśmy - przygotowując się na spotkania z nami, czytali swoje „oświadczenia” złożone przed laty dla Muzeum Auschwitz-Birkenau. I wydaje mi się, że w kilku przypadkach tak właśnie było. Chociaż oczywiście nikt w naszej obecności nie czytał tych „oświadczeń” z kartki, to z powodzeniem mógł je „czytać” z pamięci. Ale jeśli tak się zdarzyło, to mamy też dodatkowe potwierdzenie, że gdy trzeba skonstruować narrację, to ludziom - nawet „świadkom historii” - chyba znacznie łatwiej sięgać do gotowej opowieści, niż do „prawdziwych” doświadczeń. Ta gotowa opowieść nie musi być zresztą tak wyrazista, jak sformalizowane "oświadczenie” z pieczęcią Muzeum. Jeden z naszych rozmówców złożył relację dla Muzeum około roku po spotkaniu z nami. W tym późniejszym 
„świadectwie” pojawił się niejeden passus z wcześniejszego. Te same zdania i słowa - te same narracyjne konstrukty. Mimo że kontekst ich powstania, sposób prowadzenia rozmowy, jej forma, zainteresowania osoby nagrywającej były zupełnie różne. Warto dodać, że ten rozmówca otrzymał od nas - po nagraniu audio - tylko płytę z nagraniem, bez transkrypcji.

I jeszcze jedna ważna ogólniejsza uwaga w tym miejscu: na podstawie analizowanych tu relacji nie wydaje się, by duże znaczenie miał czas, jaki upłynął między skonstruowaniem obu narracji - „oświadczeń” z Muzeum Auschwitz i relacji MSDP. Te same konstrukty narracyjne są powielane przez rozmówców, niezależnie od tego, czy między powstaniem obydwu „świadectw” upłynęło lat trzydzieści, dwadzieścia, dziesięć czy tylko dwa. Chociaż wydaje się, że powtórzeń jest więcej, gdy ten czas jest krótszy. Ale to wrażenie wyjaśnić można zmianą sposobu prowadzenia wywiadów przez pracowników Muzeum Auschwitz-Birkenau. Te nowsze wydają się bardziej otwarte, dłuższe, pozostawiają więcej swobody narratorowi. Nic dziwnego, że wywołuje z pamięci więcej opowieści.

Skoro te narracyjne konstrukty są tak utrwalone i powielane - niezależnie od czasu, kontekstu i sposobu ich wywołania - to może, mimo wszystkich wspomnianych różnic, nie ma znaczenia, których $\mathrm{z}$ tych dwóch źródeł używamy w naszych badaniach historycznych? W ostatecznym rachunku chodzi przecież o to, by wydobyć interesujące nas informacje o przeszłości, a potem oczyścić je ze wszystkich „zakłóceń”. Oczywiście przy założeniu, że zasadnicza zawartość faktograficzna tych różnych źródeł jest podobna i porównywalna ${ }^{11}$.

Wydaje mi się jednak, że mimo tych podobieństw, mimo powtarzalności narracyjnych schematów, nie jest obojętne, do jakich wywiadów z byłymi więźniami sięgamy, gdy chcemy dowiedzieć się czegoś o ich kacetowym doświadczeniu, i o kacecie w ogólności. Różnica zdecydowanie wyostrza się wówczas, gdy uznamy, że ocaleni nie tylko „świadkowali” przeszłości, ale także - a może przede wszystkim - jej doświadczali. I to doświadczenie potem w sobie „przetrawiali” i między sobą oraz wobec innych je przetwarzali. I ciągle to robią w pamięci i w narracji - nawet

11 Nie biorę tu pod uwagę tych „oświadczeń”, które nawet w małym stopniu nie są autobiograficzne, lecz całkowicie tematyczne, bo koncentrują się wyłącznie na jednym, szczególnym zdarzeniu/doświadczeniu - na przykład przybyciu do obozu. Nie sposób porównywać ich dokładniej z długimi narracjami autobiograficznymi. W mojej próbce była jedna (na dziesięć) taka zupełnie 'niesymetrycza' relacja. 
jeśli powtarzają te same historie. A w tych kolejnych powtórzeniach coraz mocniej scalają fakty $\mathrm{z}$ ich interpretacjami. Jedne bez drugich nie tylko obejść się już nie mogą, ale i rozdzielić nie bardzo dają.

\section{Ruchome narracje (flexible narratives)}

Jednak relacja to nie tylko na nowo ułożona mozaika od zawsze (od 'tam i wtedy' doświadczenia) gotowych formuł, narracyjnych schematów. Porównując „oświadczenia” z Auschwitz z relacjami MSDP, znajdujemy oprócz tego, co utrwalone i powtarzalne - takie fragmenty, takie opowieści i interpretacje, które pojawiają się tylko w jednym ze źródeł. Te bardziej od kontekstu zależne narracje nazwijmy tu sobie ruchomymi.

Spróbujmy spojrzeć na autobiograficzną relację z pewnego dystansu - tak, by dostrzec ją w całości, nie traktując przy tym jako tylko źródła wiedzy o faktach z przeszłości. Mając do porównania dwie takie pełne opowieści, łatwo dostrzeżemy, że te nietrwałe, zmienne, ruchome elementy w każdej z nich w istotny sposób kształtują całość. Widzimy teraz, że te opowieści - z grubsza tak podobne w wymiarze faktograficznym w wielu szczegółach i interpretacjach są różne. Jedne tylko nieznacznie, inne jednak - dalece. Ogólniejsze spostrzeżenie jest takie, że relacje nagrywane w projekcie Mauthausen są zwykle w te szczegóły i interpretacje bogatsze. Rozmówcy mający więcej swobody, więcej przestrzeni narracyjnej łatwiej i gęściej wypełniają ją swymi opowieściami.

Wejdźmy teraz w niektóre z tych różnicujących szczegółów. Dla porządku i przejrzystości porównań podzieliłem je na dwie grupy. Pierwsza grupa to szczegóły opowieści o konkretnych zdarzeniach, wyrazistych epizodach, „przygodach”. Druga - to fragmenty bardziej refleksyjne, interpretacyjne, 'filozoficzne'. To podział służący analizie - w samych relacjach, jak już pokazywałem, jest zupełnie nieostry. Oba wymiary narracji przenikają się wzajemnie.

\section{A. Epizody, doświadczenia}

W relacji oświęcimskiej z roku 1986 pan Mirosław wspomina swój pobyt w Auschwitz. Cała relacja jest bardzo krótka, mieści się na czterech stronach maszynopisu. Ważnym, kluczowym chyba momentem tej krótkiej opowieści jest przywołanie kilkumiesięcznego uwięzienia w celi dziewiątej na bloku jedenastym. W tym czasie umierają tam na tyfus inni więź- 
niowie. Oto jaki obraz ich śmierci (i reakcji na nią) pojawia się w „oświadczeniu" dla Muzeum. Przytaczam w oryginalnej pisowni:

„W celi 9 spędziłem 4 miesiące razem z innymi współwięźniami, od 2 grudnia 1942 do 31 marca 1943 r. Przez cały ten czas nie byłem przesłuchiwany ani sądzony.

W celi numer 9 przebywało ze mną kilkunastu więźniów. W miarę upływu czasu nasza sytuacja stawała się coraz bardziej dramatyczna, gdyż słyszeliśmy odgłosy egzekucji odbywających się na dziedzińcu bloku nr 11. Na domiar złego okazało się, że byliśmy zarażeni tyfusem. Tyfus był powodem śmierci m.in. Józefa SZYJKI [tak w oryginale]. Aresztowany ze mną, w tej samej sprawie Aleksander DOMAGALIK zmarł w celi nr 9 dnia 13 marca 1943 r. Pamiętam, że po śmierci współwięźniów wymieniałem się ze zmarłymi ubraniem i butami. Pewnego dnia do celi naszej został doprowadzony jakiś więzień-Polak, lekarz pochodzący z Krakowa. Polecił, abym się rozebrał. Po dokonaniu oględzin stwierdził, że również ja miałem tyfus. W tym czasie moi współtowarzysze celi leżeli już na posadzce. Jako nieco przytomniejszy leżałem na wierzchu"12.

Po 17 latach od złożenia tamtej relacji nagrywaliśmy z panem Mirosławem wywiad wideo w projekcie dotyczącym Mauthausen. Ta późniejsza relacja jest znacznie dłuższa, trwa dwie i pół godziny, jej zapis ma około 50 stron. Jest 'gęstsza' - doświadczenia obozowe przywołane są bardziej szczegółowo. Także centralne doświadczenie pobytu w celi bloku 11 zyskuje na wyrazistości. Pojawia się więcej konkretów, są nowe fakty. Prośba o opowiedzenie historii życia oraz bardziej domowy, prywatny kontekst rozmowy zdecydowanie sprzyjają w tym wypadku narracyjnej swobodzie. I to mimo obecności kamery. Przywołam jednak tylko krótki passus, który najbardziej odpowiada - gdy idzie o treść - cytowanemu wyżej fragmentowi „oświadczenia”. Transkrypcja oddaje tu język mówiony.

„Ale jeszcze w bunkrze opowiem wam jak było. Umarł Szyjka, umarł Zamarlig, umarł Domagalik. Ja im pobrałem pieniądze. Jak który umarł i przyszedł lekarz i mówi tak: Tobie to już nic nie będzie, choćbyś na nich leżat/pod nimi. Bo to był tyfus plamisty. W tym bunkrze. Także ja przeszedłem ten tyfus. Ale jak ten umarł/ i tak wytypował ten lekarz, że tego za godzinę, tego za dwie... I patrzę - faktycznie o tej samej godzinie ten umiera i ten. Ja im

12 Relacja Mirosława C. złożona dla Państwowego Muzeum Auschwitz-Birkenau w Oświęcimiu, kolekcja Oświadczenia t. 116, s. 6o. 
pozabierałem pieniądze, marki. [niewyraźnie, śmiech] No i później jak ja na pakamerę/ Rozebrać się i wszystko wyjąć z kieszeni/ ja tyle marek mam. I esman jak zobaczył to/ Skąd?! Ja mówię, że ten umarł, ten. [z satysfakcją] Poklepał mnie, że ja dobrze robiłem. Te pieniądze zabrali i wpisali mnie. Na moje konto takie".

Nagrywający relację - prowadzący rozmowę - wraca potem do tych doświadczeń w celi na bloku jedenastym. To słynny dla pamięci Auschwitz blok śmierci. Swoją grozą przyciąga uwagę. Dzięki tym pytaniom już pod koniec nagrania dowiadujemy się nowych szczegółów o tamtym zdarzeniu:

„Siedziałem w bunkrze cztery miesiące. Wtedy nie wiedziałem, który był blokowym. Bo jak w bunkrze, to człowiek nic nie wie. Bo dopiero jak człowiek jest na bloku, to wie, który jest blokowy/ Ale w bunkrze to ja nie wiedziałem. Dawał zupę, zamknął drzwi, kibel wziął i tyle. Koniec. Ino takie okienko było i my patrzyli i po cieniu my zegar se ustawili, że jest ta godzina, ta godzina/ Podług cienia. No.../ I tak człowiek żył w tym Oświęcimiu. Pacierze mówił i patrzał ino. Jak tłukli garnkami - to, że idzie obiad $[\ldots]$

Tam nie było [przyjaźni - PF]. Ten umarł, ten umarł. Przyszli - poszli. Nie było takich no/ przyjaźni. No był taki jeden ten Domagalik, no to umarł. Był ten Szyjka. Temu Szyjce zabrałem saperki. Bo ja miałem bardzo liche buty, a on był wojskowy, saperki miał. Jak umarł to żem mu te buty wziął [uśmiech]. I pieniądze. Później na pakamerze te buty oddałem, bo mi dawali wszystko inne, no - [nagrywający] Czyli zabierał Pan zmarłym../ proszę mi powiedzieć dlaczego Pan brał od zmarłych pieniądze? - No bo mówię, te marki może się przydadzą. I tak wyjmu/ wyjąłem te marki i temu Domagalikowi i temu Szyjce i tego. I tak/ tak jakoś/ ja nie wiem co to było, że wiedziałem. Bo każdy, że/ bo jak my w bunkrze jesteśmy koledzy, nie. No to wiemy, ten ma tyle ma. A co Ci te marki? Trzeba było cicho, się nie odzywać. No ale później jak umarł, to żem wziął te marki. I dzięki tym markom, może miałem te kantynę to.../ Także, no... - [nagrywający] A buty wziął Pan dlatego, ponieważ.../ - Żem miał liche, a on miał dobre. Saperki"13.

13 Relacja Mirosława C. nagrana w projekcie MSDP, sygnatura w Archiwum Historii Mówionej Ośrodka KARTA: MSDP_162; w Archiwum Mauthausen w Wiedniu: OH/ $\mathrm{ZP} 1 / 792$. 
Jak widać ta 'odpowiedniość jest nieoczywista. Gdy porównamy faktografię tych dwóch relacji widzimy, że nie brak drobnych i większych różnic. Zwłaszcza tej, że najpierw są tylko buty, potem - i buty i pieniądze. Oba teksty nieźle się jednak uzupełniają. Gdy natomiast skupimy się na interpretacjach tych zdarzeń, towarzyszących im (a raczej pamięci o nich) emocjom, nadawanych im znaczeniom - widzimy raczej różnice niż podobieństwa. Relacja spisana w Muzeum w Oświęcimiu jest wtedy tylko ramowym szkicem, w porównaniu z późniejszą opowieścią - swobodną, otwartą, nieoficjalną, głębszą.

Oba zapisy to ostatecznie zupełnie inne teksty - należące do różnych gatunków, wytworzone w zupełnie innej interakcji. Chociaż pozornie tak podobnej, bo przecież tam i tu była to rozmowa. Ale definicja obu tych rozmów, obu sytuacji składania „świadectwa” była za każdym razem chyba zupełnie różna. I to po obu stronach. A może to także przykład nieoczywistej pracy pamięci? Im dalej od traumatycznych obozowych doświadczeń, tym opowieść o nich mniej skrępowana, bardziej 'szczera'?

W relacji pana Dyonizego nagranej w ramach MSDP pojawia się wiele narracyjnych konstruktów, które utrwaliły się w jego pamięci. Że to takie właśnie trwałe struktury, dowiadujemy się z porównania tej narracji z „oświadczeniem” zarchiwizowanym 5 lat wcześniej, w 1997 r., w Muzeum Auschwitz-Birkenau. Już przy pobieżnej lekturze widać jednak, że i w tym wypadku obie opowieści wyraźnie się różnią. Ta późniejsza jest dłuższa, bardziej szczegółowa. Zwłaszcza w tych częściach, które dotyczą pobytu w Gusen (największym i najbardziej 'polskim' podobozie Mauthausen), wyzwolenia, powrotu do domu oraz przed-i powojennych doświadczeń narratora-bohatera. Wyjaśnienie jest tu proste - Muzeum koncentruje się na historii Auschwitz, wywiady MSDP starano się prowadzić jako biograficzne, całościowe.

Ale gdy zanurzymy się w obie te relacje nieco głębiej, dostrzeżemy, że w tej późniejszej, mauthausenowej pojawia się obraz dotyczący Auschwitz nieobecny w „oświadczeniu” oświęcimskim. Tak się składa, że i on dotyczy pobytu na bloku 11 - bloku śmierci. To potwierdza symboliczne znaczenie tego miejsca dla więźniarskiej (ściślej: oświęcimskiej) wspólnoty pamięci. Na pytanie prowadzącej rozmowę, czy ten barak różnił się od pozostałych, słyszymy taką odpowiedź: 
„Tak, myśmy byli odgrodzeni murem, z tym, że myśmy przylegali do bloku 13. Na bloku 13 było Sonderkommando, a na 11 karna kompania. I budynek, który nas dzielił między te/ to był Waschraum i część/ połowa Waschraumu należała do karnej kompanii, a druga połowa, zamurowana, do Sonderkommando. Także myśmy tylko słyszeli się przez ten... A kontaktów żadnych. No wiadomo było - jak przychodziło Sonderkommando to ich było czuć. Ten pot, następnie smród z ubrań, które.../ bo oni później spalali zwłoki. Na zewnątrz, bo krematoria nie nadążały przerobić, więc to, to się odbywało na zewnątrz"14.

Drobiazg, który do faktograficznej wiedzy o Auschwitz nic nowego już pewnie nie wnosi. Ale wart odnotowania jako przykład tego, że pamięć puszczona trochę swobodniej, (re)konstruować potrafi nie tylko obrazy, ale też - na przykład - zapachy. Ten akurat jest dla pamięci o doświadczeniu uwięzienia w kacecie szczególnie znaczący. I może nie tylko dla tej indywidualnej pamięci byłego więźnia.

W grudniu 1973 r. pan Zygmunt złożył długą, bardzo szczegółową relację - „oświadczenie” dla Państwowego Muzeum Auschwitz-Birkenau. Ta relacja w dostępnej nam postaci - czyli jako zredagowana transkrypcja, traktowana tu jako podstawowe źródło - wygląda tak, jakby jej podstawą była swobodna, rozbudowana naracja autobiograficzna. Obfituje w obrazy, epizody, mikroopowieści o wielu bardzo konkretnych doświadczeniach. Mimo to, gdy porówna się ją z wywiadem przeprowadzonym w roku 2002 w projekcie dotyczącym Mauthausen, widzimy jak wiele w niej braków, pominięć. Jak wiele doświadczeń zostało tu 'zapomnianych'. A może wtedy jeszcze nie były tak wyraźnie pamiętane?

Co ciekawe, to 'zapomnienie' dotyczy nie tylko drobiazgów, lecz także spraw i zdarzeń kluczowych dla pełniejszego zrozumienia doświadczeń narratora. Przynajmniej takimi - ważnymi - mogą się wydawać, gdy już je poznamy. Bez tej porównawczej wiedzy obie narracje mogą być równie całościowe, co fragmentaryczne. Ale gdy mamy obie, widzimy, że różni-

14 Relacja Dyonizego L. nagrana w projekcie MSDP, sygnatura w Archiwum Historii Mówionej Ośrodka KARTA:

MSDP_o34; w Archiwum Mauthausen w Wiedniu: OH/ZP1/792. 
ca jest istotna. Oto dwa wyraziste przykłady 'przypomnienia sobie' przez rozmówcę ważnych doświadczeń obozowych w relacji nagranej w ramach Mauthausen Survivors Documentation Project w 2002 r. Albo ich 'zapomnienia’ przy składaniu „oświadczenia” dla Muzeum.

"Chodziło się na te prace rozmaite po domach, po esesmańskich, bo to było/ po osiedlach, po tych osiedlach, po obozach niektórych, nawet miałem raz wypadek, że zawieźli mnie do/ autem do takiego sanatorium esesmańskiego koło/ niedaleko Wadowic, zapomniałem w tej chwili jak się nazywało. Oni tam mieli takie małe sanatorium. Do/ do anteny/ Uziemienie czy coś tam takiego, tam robiłem do/ do urządzeń. Tak daleko mnie zawieźli wtedy. Pamiętam, że ten esesman co mnie konwojował, potem szedł do restauracji, no a nie mógł beze mnie iść, to szedł ze mną do tej restauracji coś wypić, czy zjeść, nie wiem. No i tam w restauracji ta pani co jest, widzi, że z więźniem idzie i/ czy może mi coś dać. - Może dać. No to dostałem jedzenie od ludności cywilnej".

I jeszcze jeden obrazek z tej samej relacji:

„Ja się palić nauczyłem dopiero w obozie, ze strachu. Ze strachu i ze zdenerwowania. Jak człowiek widział te rozstrzeliwania, tyle tych, tych zwłok, trupów, jak to wywozili te trupy z bloku jedenastego wywozili na wozach, ta krew kapała. Tę krew można było widzieć, nie. Byłem w kompanii karnej, tam palić nie było wolno. Gdzie nie było wolno palić. I nie było co palić! Bo skąd?! To tam się nauczyłem palić. Jak się paliło? Jak się znalazło kawałek papierosa na ziemi, albo się od kogoś dostało, to dym się dmuchało po ścianie, żeby dym nie wycho/ się nie rozchodził po pokoju. Tylko po ścianie się rozwlekło, żeby nikt nie widział, że się paliło papierosa. I miałem też wypadek, ale to już byłem/ w Gusen byłem, że sprzedałem za papierosa. To pierwszy raz sprzedałem chleb za papierosa i więcej razy tego nie robiłem, bo bym zdechł, cholera jasna. Bo pajdkę chleba Pan dostał i próbował Pan jeszcze/ za jednego papierosa pan sprzedał. Raz tak zrobiłem i już więcej nie paliłem"15.

15 Relacja Zygmunta K. nagrana w projekcie MSDP, sygnatura w Archiwum Historii Mówionej Ośrodka KARTA:

MSDP_101; w Archiwum Mauthausen w Wiedniu: OH/ZP1/559. 


\section{B. Refleksje, interpretacje}

Zatrzymajmy się teraz przez chwilę przy tych fragmentach relacji, w których rozmówcy mniej koncentrują się na opisie samych zdarzeń, a mocniej na ich interpretacjach. Interpretacje, jak widzieliśmy przed chwilą, są już zawsze częścią opowieści o faktach. Po raz kolejny można przypomnieć, że te ostatnie nie są przecież dane wprost (cóż miałoby to w ogóle znaczyć?), lecz przez doświadczenie, pamięć i narrację. Ale oprócz tych 'wewnętrznych', często nieuświadomionych i niezauważanych - ani przez narratorów, ani ich słuchaczy/czytelników - są także interpretacje 'zewnętrzne', 'samodzielne', wyraźne. Mogę odnosić się do konkretnych zdarzeń, ale także, jak w przypadku analizowanych tutaj relacji obozowych, do przetrwania kacetu jako całościowego doświadczenia ludzkiego. Niektóre są czymś jeszcze ogólniejszym - swoistymi filozofiami własnego życia. Albo życia w ogóle.

Te podziały, podobnie jak poprzednie, nie są ostre. Ale przecież nie o logicznie poprawne klasyfikacje tu idzie, lecz o zwrócenie uwagi na kilka ważnych tropów obecnych w tych świadectwach i o ułatwienie ich porównawczej lektury. Porównanie relacji oświęcimskich z tymi z Mauthausen ze względu na takie 'zewnętrzne' interpretacje, filozofie przetrwania i ocalenia, metarefleksje o własnym doświadczeniu obozowym, daje dosyć jasny obraz. Ten wymiar doświadczenia jest - z małymi wyjątkami - słabo obecny w „oświadczeniach” z Muzeum Auschwitz-Birkenau. Mógł być ważny w czasie składania samej relacji, słyszalny w głosie, i widziany w twarzy rozmówcy, ale w zredagowanym tekście złożonym w archiwum, gdzieś się zapodział.

Inaczej w otwartych wywiadach nagranych w projekcie MSDP - tutaj ten wymiar obecny jest wprost, 'na powierzchni'. I nie tylko dlatego, że prowadzący te nagrania o niego dopytywali. Także dlatego, że rozmówcy czuli się swobodniejsi, by o nim powiedzieć. Swobodniejsi, by odsłonić przed nami swoje rozumienie tego, co ich spotkało. Oczywiście to nie tylko technika prowadzenia wywiadu ma tutaj znaczenie. Także miejsce i kontekst, w jakim się odbywa oraz - być może największe - biograficzny moment, w którym rzecz się wydarza. Relacje w projekcie Mauthausen zbierane były naprawdę u schyłku życia rozmówców, niejedna - w ostatnim możliwym momencie.

Gdy sięgamy po taką relację audio/wideo i słyszymy/widzimy ten jej interpretacyjny wymiar, nie mamy wątpliwości, że wart był utrwalenia, że jest ważny. Ważny dla opowieści jako całości, ale także dla zawartej 
w niej, i zwykle dominującej, warstwy faktograficznej. Nadaje jej bowiem dodatkowe, autobiograficzne sensy. Pozwala inaczej, chyba pełniej, ją rozumieć. Lepiej więc dobrze służy późniejszym badaniom, bo otwiera nowe ich możliwości. Pod warunkiem, rzecz jasna, że chodzi w nich o coś więcej niż o inwentaryzację faktów.

Przyjrzyjmy się kilku takim interpretacyjnym fragmentom w przykładowych relacjach MSDP.

Jesienią 2001 roku pan Józef udzielił wywiadu historykowi z Państwowego Muzeum Auschwitz-Birkenau' ${ }^{16}$. Ten wywiad stał się postawą zredagowanego tekstu relacji, który znalazł się w zbiorze „oświadczenia”. Z lektury tego dokumentu dowiadujemy się, że przed uwięzieniem w Auschwitz rozmówca spędził 421 dni w jednoosobowej celi więzienia Gestapo w Opolu. Widać, że było to centralne doświadczenie biograficzne narratora. Widać jednak również, że prowadzący rozmowę nie był nim szczególnie zainteresowany. Tym, co go interesowało był późniejszy pobyt narratora w obozie Auschwitz. To był wywiad dla Muzeum tego obozu, nietrudno więc wytłumaczyć, skąd taka koncentracja na jego historii i na tym fragmencie losów rozmówcy. Prowadzący popycha go więc do przywoływania wspomnień związanych z Auschwitz. Redukując przestrzeń komunikacyjną i eliminując z niej ‘szumy', otrzymuje rzeczową opowieść na zadany temat.

Nie znałem tej relacji, gdy mniej więcej rok później spotkałem się z panem Józefem i poprosiłem, by opowiedział mi swoją historię życia. Przyszedłem do niego w roli osoby nagrywającej wywiady w międzynarodowym projekcie dokumentacyjnym dotyczącym kompleksu obozów Mauthausen. Mój rozmówca był jego więźniem. Chociaż doświadczenie pobytu w Mauthausen było powodem naszego spotkania, nie starałem się popychać i 'przyspieszać' pamięci mego rozmówcy w tę stronę. Zgodnie z założeniami przyjętej metody starałem się raczej iść za opowiadaną mi swobodnie historią, pozwalać się w nią wciągać. Auschwitz było tematem ważniejszym niż Mauthausen, ale znacznie ważniejsza od opowieści o Auschwitz była dla narratora opowieść o pobycie w samotniczej celi opolskiego więzienia. To był ostatecznie centralny temat relacji, jaką zarejestrowałem. Nie mogło być inaczej, skoro jest to także kluczowe doświadczenie biograficzne mego rozmówcy, stanowiące dla jego narracyjnej tożsamości.

16 Relacja Józefa N. dla Państwowego Muzeum Auschwitz-Birkenau, kolekcja Oświadczenia, t. 151, s. 85-93. 
Gdy porównuję obie te relacje, widzę, że w tej późniejszej nie brakuje żadnej opowieści, nie brakuje żadnego faktu, który pojawił się w tej pierwszej. Jest natomiast wiele więcej. Owo więcej, to przede wszystkim właśnie interpretacja - zapis sensotwórczej pracy pamięci. Tym doświadczeniem, które w taką metaopowieść najbardziej obrasta, jest oczywiście pobyt w gestapowskim więzieniu. Okazuje się - czego nie sposób wyczytać w „oświadczeniu” oświęcimskim, ani z niego wywieść, że tym, co czyni tamto doświadczenie tak wyjątkowym, jest właśnie samotność. Nie warunki życia, strach, przesłuchania, niepewność o własny los, ale właśnie samotność - 421 dni w pojedynczej celi.

„To było [praca przy skubaniu gęsiego pierza - PF] błogosławieństwem. Och, to są zupełnie historie inne, psychologiczne historie. Więc te różne przemyślenia. I dekalog. I co ja tam nie myślałem o różnych rzeczach. I taki był incydent/ Polakom nie dawali książek do czytania [...] I otwieram drzwi... Książka! No i ta książka... To był tygodnik Las, Wald. I cały rocznik tak był wpięty w jeden tom. I tak przeglądałem, to miałem z tydzień, czy ze dwa. Później znaleźli i wzięli mi to, zabrali. I tam była taka ładna leśniczówka. A to był okres, kiedy się zastanawiałem, czym być. Jak przeżyję, bo przecież wiadomo - szanse były nijakie. Taki epizod właśnie”.

Ten epizod miał kontynuację w powojennej biografii narratora. Okazał się bowiem kluczowy dla jego późniejszej decyzji o wyborze zawodu leśniczego. O „pójściu do lasu”, jak mówił.

„Później przystąpiłem do realizacji swoich marzeń z więzienia, a więc pracy w lesie. Udało się to. Kilkanaście lat pracowałem w leśnictwie"17.

Mam przekonanie, że takie interpretacyjne wspomnienie może być ważne także dla historyka skupionego na poszukiwaniu faktów z przeszłości. Sposób, w jaki pan Józef „przetrawił” swoje doświadczenia wojenne, zwłaszcza doświadczenie uwięzienia przez gestapo, miał bardzo realne konsekwencje biograficzne - dotyczące sfery twardych faktów. Wprost ukształtował jego życiową drogę, a przynajmniej jej ważny fragment.

Przywołam jeszcze jeden passus z tej samej relacji, bo nieźle pokazuje jak indywidualna, więc subiektywna, interpretacja przeszłych doświadczeń wyznaczać może późniejsze decyzje i życiowe wybory.

17 Relacja Józefa N. nagrana w projekcie MSDP, sygnatura w Archiwum Historii Mówionej Ośrodka KARTA:

MSDP_o85; w Archiwum Mauthausen w Wiedniu: OH/ZP1/397. 
Po wyzwoleniu obozu Mauthausen i powrocie z Austrii, a przed wzmiankowanym „pójściem do lasu”, pan Józef podjął pracę w administracji lokalnej, na stanowisku osoby odpowiedzialnej za organizowanie wysiedleń Niemców. Wysiedlenia poprzedzały trwającą już akcję osiedlania się „repatriantów” ze Wschodu na tych „odzyskanych” ziemiach. Obie akcje były skoordynowane i, jak wynika z relacji, na lokalnym poziomie mogły być kierowane przez tę samą osobę. Rzecz działa się w jednym z miasteczek Dolnego Śląska.

„Po wojnie wyszedłem. No to do działania trzeba było się jakiegoś wziąć i padło na to, żebym zajął się wysiedlaniem Niemców z Dolnego Śląska. Trafiło na Głuszycę koło Wałbrzycha. No i tam byłem takim przewodniczącym, miasto jest gdzieś rzędu 15 tysięcy mieszkańców. No i to trzeba było wszystko wysiedlić. To jest osobny temat, różnie się mówi na ten temat, że to i wstydliwy i taki czy inny, ale w moim odczuciu to jak ja to robiłem i widziałem, to raczej w porządku".

I dalej, poproszony o opowiedzenie o tych swoich tuż-powojennych doświadczeniach:

„...oczywiście niektórzy tam z płaczem tego, jak to zwykle wyrzucając z mieszkań no to.../ Człowiek po tej wojnie był na wpół zdziczały, no to nie był problem, ale jak teraz by przyszło wyrzucić, to... [...] To było rotacja, bo to ze wschodu jednocześnie sprowadzali, a tych wysiedlali to było takie $\operatorname{tam}^{\prime 18}$.

Właściwie wszystkie podane dotąd (i wiele więcej, na które brak tu miejsca) przykłady rozbieżności między relacjami-„oświadczeniami” zgromadzonymi przez Muzeum Auschwitz-Birkenau a relacjami-autobiografiami tych samych byłych więźniów nagrywanymi w ramach Mauthausen Survivors Documentation Project, wyjaśnić można w podobny sposób. Ten sposób to odniesienie do okoliczności powstania każdego z tych „świadectw”, stojącej za nimi ludzkiej interakcji, jej postrzegania i definiowania przez zaangażowane w nią osoby (i instytucje). Takie wyjaśnienie możemy nazwać mikrosocjologicznym. Nie mniej ważny wydaje się także biograficzny punkt czy moment, w którym powstaje opowieść.

18 Ibidem. 
Nie jest całkiem obojętne (a bywa że jest to kluczowe), w jakim momencie życia zapisuje się czyjeś wspomnienia o pozornie zamkniętej przeszłości. Ludzka pamięć jest bowiem bardziej procesem niż archiwum. To wyjaśnienie można pewnie nazwać psychologicznym. Gdy taki zapis dokonuje się w ostatniej niemal możliwej chwili, staje się on szczególnym „świadectwem". Zwłaszcza wtedy, jak w naszym tutaj przypadku, gdy wspomnienia dotyczą traumy prześladowań, bycia ofiarą. Jesteśmy skłonni traktować je wówczas jako swego rodzaju moralne przesłanie, lekcję historii, która nie może się już nigdy powtórzyć. Choć takie późne albo ostatnie świadectwo bywa nazywane „testamentem ocalonego”, istotnie różni się od testamentu. Nie znosi ono, nie odwołuje zapisów wcześniejszych, poprzednich testamentów. Choćby późniejszy był najbardziej 'prawdziwy' (historycy uważają raczej, że im późniejszy, tym mniej 'prawdziwy').

Te wszystkie wyjaśnienia różnic między „świadectwami” tych samych osób, złożonymi w różnych momentach i różnych sytuacjach, koncentrując się na metodologii oral history, na metodzie dokumentacji, na pamięci, na interakcji i na podobnych szczegółach, zupełnie pomijają sprawy bardziej zasadnicze. Do nich pewnie należy szerszy kontekst historyczny, społeczny, polityczny, w jakim każde zdarzenie - także takie jak złożenie relacji albo udzielenie wywiadu - jest (było) osadzone.

Zatem, czy jakieś - a jeśli tak, to jakie - różnice między analizowanymi tutaj przeze mnie relacjami dałoby się wyjaśnić poprzez taki szerszy kontekst? Dziesięć „oświadczeń” i tyleż relacji to materiał za mały na formułowanie mocnych uogólnień. Ale jakieś odpowiedzi się tu jednak nasuwają. Jest na przykład dość charakterystyczne, że w starszych „oświadczeniach” - tych z lat sześćdziesiątych, siedemdziesiątych czy osiemdziesiątych ubiegłego wieku - nie znalazłem żadnego odwołania do religii i wiary w Boga, które miałoby moc metafizycznego usensownienia doświadczeń obozowych albo służyło interpretacji ocalenia. Ta nieobecność Boga w tamtych starszych „świadectwach”, kontrastuje mocno z jego obecnością w relacjach późniejszych, zwłaszcza tych autobiograficznych, swobodniejszych, bardziej narracyjnych. Nie tylko zbieranych w projekcie MSDP, lecz także gromadzonych w Muzeum Auschwitz-Birkenau w ostatnich latach. Widać to było choćby w cytowanej na początku relacji pana Floriana, należącej do tego zbioru. W tamtym fragmencie mieliśmy „świadectwo” boskiej opatrzności w jakiejś konkretnej sytuacji obozowej. Nie brakuje jednak odniesień bardziej fundamentalnych, które mają podkreślać uczestnictwo w jakimś szerszym boskim planie. 
„Wiara jest ważna, bo wiara podtrzymywała na duchu w obozie. Mówiłem o tym medaliku, co kolega mi przekazał i powiedział: «Ten medalik przyniósł szczęście mojemu bratu, mnie, może i tobie przyniesie». Choć nie było wolno nosić. I przyniósł mi szczęście, jak tu nie wierzyć. Pan może być niewierzący, ale ja jako wierzący mam teraz namacalny dowód, że mi to jednak szczęście przyniosło"19.

I jeszcze kilka przykładów takich odwołań. Nietrudno byłoby przytoczyć ich wiele więcej - nawet na podstawie kilku zaledwie relacji. I wszystkie byłyby dosyć podobne.

„Zmówiłem [w obozie - PF] miliony pacierzy”, a w innym miejscu tej samej relacji: „Nieraz sobie mówię, że dzięki Bogu [ocalałem - PF]. Człowiek się ino modlił”20, i jeszcze taki passus: „Tak. Tyle, co ja się namodliłem w więzieniu, jak sam siedziałem w celi, to chyba nigdy w życiu więcej"21. Znamienne, że niemal identyczne zdanie pojawia się w zupełnie innej relacji ${ }^{22}$.

Jeśli doświadczenie religijne było w obozie tak ważne, to co się z nim działo w międzyczasie. W swych starych relacjach złożonych dla Muzeum ocaleni, tak pewni Bożej opatrzności, trzymają się z dala od religii i metafizyki. Dlaczego? Bo nie pytano ich o to (myśmy w MSDP często pytali), a głupio było samemu „z czymś takim wyjeżdżać”? Jakoś nie wypadało? A może nie tylko nie wypadało, ale nie bardzo było wolno? A może to wszystko jako nieistotne i nie na temat przepadło między wypowiedzianym słowem a zredagowanym zapisem „oświadczeń”? A może tutaj także decyduje wiek rozmówcy - bliskość śmierci sprzyja poszukiwaniu głębszych sensów i Boskiej opatrzności, bez której kiedyś łatwiej można się było obejść. A te akurat poszukiwania prowadzić można wstecz, reinterpretując swoje odległe doświadczenia.

19 Relacja Zygmunta K. nagrana w projekcie MSDP, sygnatura w Archiwum Historii Mówionej Ośrodka KARTA: MSDP_101; OH/ZP1/559.

20 Relacja Mirosława C. nagrana w projekcie MSDP, sygnatura w Archiwum Historii Mówionej Ośrodka KARTA: MSDP_162; w Archiwum Mauthausen w Wiedniu: OH/ $\mathrm{ZP} 1 / 792$.

21 Relacja Floriana G. nagrana w projekcie MSDP, sygnatura w Archiwum Historii Mówionej Ośrodka KARTA:

MSDP_o86; w Archiwum Mauthausen w Wiedniu: OH/ZP1/382.

22 Relacja Edwarda P. nagrana w projekcie MSDP, sygnatura w Archiwum Historii Mówionej Ośrodka KARTA: MSDP_o92; w Archiwum Mauthausen w Wiedniu: OH/ $\mathrm{ZP} 1 / 380$. 
Tropów jest tu wiele, to tylko niektóre. Żaden nie prowadzi do jednej i pewnej odpowiedzi.

Ale te odwołania do religii i do Boga tylko w nowszych relacjach, to nie jedyne - chociaż zapewne najbardziej wyraziste - które wyjaśnić można szerszym kontekstem społeczno-politycznym, w jakim powstają relacje „świadków”. Te niereligijne są trudniejsze do odnalezienia - znacznie głębiej skrywają się w relacjach (i transkrypcjach). Spróbuję jednak przywołać kilka ich przykładów:

Pan Edward to stary więzień Auschwitz, do obozu trafił w pierwszym transporcie - w czerwcu 1940 r. Swoje „oświadczenie” dla Muzeum obozu złożył już w roku $1960^{23}$. Tamto „oświadczenie” zupełnie nie przypomina swobodnej relacji, dużo bardziej natomiast zapis przesłuchania prokuratorskiego. Taka była wówczas praktyka wywoływania źródeł przez Muzeum, jego „filozofia dokumentacji”. Pan Edward miał zresztą więcej doświadczeń bycia przesłuchiwanym - uczestniczył jako świadek w kilku procesach sądowych przeciwko nazistowskim zbrodniarzom ${ }^{24}$. To też miało zapewne wpływ na treść i formę jego pamięci o obozie, na jego „świadectwo”. W „oświadczeniu" zarchiwizowanym w Muzeum pan Edward przywołuje hasłowo udział w wojnie obronnej 1939 r., po czym od razu przechodzi do swoich doświadczeń obozowych. Przywołując te ostatnie, sporo uwagi poświęca obozowej konspiracji i w tym kontekście trzykrotnie wspomina Józefa Cyrankiewicza - byłego więźnia Auschwitz i Mauthausen, członka ruchu oporu, premiera RP w latach 1947-1952 i PRL w latach 1954-1970, wieloletniego szefa Związku Bojowników o Wolność i Demokrację - centralnej, upolitycznionej organizacji kombatanckiej w PRL. Jedno z tych przywołań jest następujące:

„Bezpośrednio po 27 X [1944 r. - PF] spotkałem w bloku 20 więźnia Cyrankiewicza Józefa, o którym wiedziałem, że przewodzi grupą Ruchu Oporu i otrzymałem od niego polecenie zachowania spokoju i zaniechania na pewien czas jakichkolwiek kontaktów"25.

Nic podobnego nie pojawia się w relacji biograficznej złożonej przez pana Edwarda w 2002 r. w ramach Mauthausen Survivors Documentation

23 Relacja Edwarda P. dla Państwowego Muzeum Auschwitz-Birkenau, kolekcja Oświadczenia, t. 12, s. 44-6o.

24 W roku 1964 był także świadkiem oskarżenia we frankfurckim procesie przeciwko załodze Auschwitz-Birkenau.

25 Relacja Edwarda P. dla Państwowego Muzeum Auschwitz-Birkenau, kolekcja Oświadczenia, t. 12, s. 58. 
Project ${ }^{26}$. Owszem, nazwisko Cyrankiewicza pojawia się i w tej relacji ostatecznie znali się w obozie, choć nie sposób rozstrzygnąć jak blisko ale przywołane jest z dystansem. Akcent pada na inny epizod dotyczący Cyrankiewicza, który jako polityk powojennego komunistycznego rządu i szef organizacji zrzeszającej byłych więźniów, pisze list do narratora, w którym oferuje swoją pomoc byłemu współwięźniowi, może koledze z kacetu. Dowiadujemy się także, że narrator odpowiedział wprawdzie na ten list, ale odrzucił ofertę pomocy, gdyż jej nie potrzebował. Nigdy później nie mieli już ze sobą żadnego kontaktu. Można to uznać za niewiele znaczący passus, dotyczący „przepracowywania” swojego obozowego doświadczenia. Można jednak także widzieć w tym wspomnieniu sprzed kilku lat pewną deklarację polityczną - dystans do Cyrankiewicza odsłania tu chyba dystans do ustroju politycznego powojennej Polski.

Taką interpretację wzmacnia inny fragment tej samej relacji, w którym rozmówca mocno podkreśla, że nienawidził „Sowietów”. Ten negatywny stosunek do Rosjan, jest uogólnieniem, ale odniesionym w relacji do konkretnego doświadczenia obozowego - mianowicie do uwięzienia w Gusen. W tym podobozie Mauthausen dużą grupę więźniów - obok Polaków - stanowili „czerwoni”, republikańscy Hiszpanie. Rozmówca wspomina, że przekonywali go oni do swoich lewicowych poglądów. On jednak przekonać się nie dał, a argumentem przeciw były jego wcześniejsze, negatywne doświadczenia z „Sowietami”, nienawiść do nich.

W relacji MSDP pojawia się jeszcze jeden wątek „polityczny”. To wspomnienie spotkania po powrocie z obozu z przedwojennym kolegą, który przestrzega przed utrzymywaniem z nim dalszych kontaktów. To niebezpieczne, bo należy do antykomunistycznego podziemia. Kontaktów więcej nie było - kolega i jego brat krótko później zginęli.

Oczywiście żadnej z tych wyraźnych (anty-)politycznych deklaracji nie znajdziemy w „oświadczeniu” oświęcimskim z 1960 r. Nie ma tam ani dystansu do Cyrankiewicza, ani krytyki ustroju powojennej Polski, ani potępienia Sowietów, ani wzmianki o kolegach w podziemiu.

Nie ma także w tamtej starej, oświęcimskiej relacji słowa o wierze, o stosunku do Boga podczas pobytu w obozie. Tymczasem - co potwierdza

26 Relacja Edwarda P. nagrana w projekcie MSDP, sygnatura w Archiwum Historii Mówionej Ośrodka KARTA: MSDP_o92; w Archiwum Mauthausen w Wiedniu: OH/ $\mathrm{ZP} 1 / 380$. 
wcześniejsze rozpoznanie - ten wątek mocno pojawia się we wspomnieniu nagranym przed kilku laty.

Wszystkie te przykłady wskazują na to, że nawet te fragmenty relacji, które wydawać nam się mogą czysto faktograficzne, uwikłane są w szersze konteksty, w jakich powstaje narracja o tych zdarzeniach. Także w kontekst polityczny. Jeśli zechcemy tych „świadectw” uważnie słuchać i je czytać - a jeszcze lepiej porównywać z innymi - powiedzieć coś mogą nie tylko o rzeczywistości, do jakiej się wprost odnoszą, także o tej, w jakiej zostały skonstruowane.

Podobne wnioski wywieść można z dalszych porównań różnych relacji tych samych osób. Pan Stefan w wywiadzie wideo nagranym w ramach MSDP z dużą wiernością odtwarza wiele narracyjnych konstruktów, które znajdziemy w jego „oświadczeniu” dla Muzeum Auschwitz-Birkenau z roku 1970. Aż trudno dać wiarę, że między złożeniem obu świadectw minęło ponad trzydzieści lat. Ale są też subtelne różnice, które ten dystans zaznaczają. Otóż z relacji oświęcimskiej nie sposób się na przykład dowiedzieć, że starszy brat rozmówcy był mocno zaangażowany w ruch oporu, w politykę, że należał do Armii Krajowej, za co został aresztowany i poddany represjom. W relacji oświęcimskiej jest wprawdzie wzmianka o bracie i jego aresztowaniu, ale brakuje jakiegokolwiek wyjaśnienia, co było jego powodem i jakie były tego konsekwencje. Narrator wtedy tego nie wiedział? Czy raczej 'zapomniał' powiedzieć? I dlaczego teraz pamięta i w jakiś sposób 'chwali się' bratem, jest z niego dumny? A może był i wtedy, tylko w 1970 r. jakoś głupio było o tym wprost powiedzieć przedstawicielowi państwowej instytucji - Muzeum Auschwitz-Birkenau? A może bał się konsekwencji takiego przyznania (się), takiego wyznania?

W tej samej relacji ze zbioru MSDP pojawia się jeszcze inny wyraźny moment, którego brakuje we wcześniejszym „oświadczeniu”. To obrazek z okupowanej Warszawy. Rozmówca wspomina, że razem z kolegami chodzili na cmentarz wojskowy i dekorowali mogiły żołnierzy poległych w wojnie 1939 r. miniaturkami flag narodowych. I znów nie ma jednej odpowiedzi, skąd ta scena tylko w tym jednym wspomnieniu - interpretacji może być tu wiele.

Kolejny wyrazisty fragment różnicujący oba „świadectwa” pana Stefana wywołany pytaniem zadanym przez nagrywającego relację dla Mauthausen. Pytanie dotyczyło ważnych konsekwencji doświadczenia obozowego w późniejszym życiu. Oto odpowiedź rozmówcy: 
„Mogę powiedzieć, że z jednej strony jak człowiek był w obozie, to cierpiał, ale z drugiej strony to ten obóz nauczył życia”.

I w innym miejscu, zapytany przez prowadzącego nagranie o tę obozową naukę, którą - co warto może dodać - otrzymał w wieku 14 lat, mówi: „...przede wszystkim to samodzielności, tak zwane kombinowanie, człowiek był zaradny. Nawet za PRL było takie przysłowie: nie będziesz kradł, nie będziesz jadł. I tak było, nieważne, ile zarabiasz, ważne jak żyjesz. To z jednej strony cierpienie, a z drugiej szkoła życia"27.

W 1970 r. takiego pytania nie zadano, ale gdyby ono padło, odpowiedź byłaby przypuszczalnie nieco inna, może mniej skonkretyzowana.

Kolejnym znakiem czasu i okoliczności, w jakich powstaje „świadectwo”, jest manifestowany stosunek do Niemców i języka niemieckiego. Tu porównanie znowu jest niesymetryczne, bo w „oświadczeniach” oświęcimskich, które analizowałem, nie ma wyrażonych wprost uogólnień na temat Niemców. Jest za to mnóstwo przykładów okrucieństwa i zbrodni popełnianych przez Niemców - nazistów. Inaczej w analizowanych relacjach z projektu o Mauthausen. Tutaj byli więźniowie konstruują takie uogólnienia. Nierzadko przy tym podkreślając, że w miarę upływu czasu ich dawny, jednoznacznie negatywny stosunek do wszystkich Niemców, języka niemieckiego, niemieckości zmienia się - łagodnieje, niuansuje się, „normalnieje”.

„Nie [chciałem - PF] zemsty, ale miałem uraz. Do Niemców! Szczególnie do Niemiec/ nie znosiłem niemieckiej mowy. Cholernie mnie/ jak ktoś po niemiecku coś powiedział, to mnie krew zalewała. Mimo że byłem z tych terenów, to mnie krew zalewała. I miałem uraz. I był później taki okres, to się/ Bardzo się to zmieniło od chwili/ w '89 roku jak pojechałem do Niemiec z Kolbe-Werke. Kolbe-Werke urządzał takie z nami spotkania. Urządzali no, te wyjazdy do Niemiec, po 19, 20 osób nas wyjeżdżało. I ja na takim jednym wyjeździe byłem, żona też była na takim wyjeździe. I tam poznałem Niemców. To byli zupełnie inni Niemcy, bardzo religijni byli przede wszystkim i bardzo/ jak tak z nimi rozmawiałem to bardzo żałowali tego/ i współczuli nam. Zupełnie inni Niemcy! Nie ci Niemcy, co ich znałem ja/ jako Hakatystów, jako tych ludzi, co nienawidzili drugich. To byli inni ludzie. I od tego czasu się zmieniło. [...] Ja osobiście po

27 Relacja Stefana S. nagrana w projekcie MSDP, sygnatura w Archiwum Historii Mówionej Ośrodka KARTA: MSDP_159; w Archiwum Mauthausen w Wiedniu: OH/ $\mathrm{ZP} 1 / 789$. 
wojnie to ich dobrze wspominam. I teraz jak tak podają w telewizji/ zresztą pojednanie, cholera to mówię, to nie można wiecznie żyć nienawiścią, tylko trzeba przecież przełamać. Tym bardziej, że tyle lat minęło - to się zaciera. A drugie, że jednak oni dosyć dużo dobrego zaczęli, paczki posyłali. Jest gość jeden, co nam posyłał paczkę od osiemdziesiątego któregoś roku. Ja go nie znam! Co roku od niego otrzymujemy paczkę na święta Bożego Narodzenia. Ja tego człowieka nie znam! Raz, jak była taka akcja z Niemiec, że pomagali wszystkim Polakom, to wysłałem podziękowanie za tę paczkę. I od tego czasu co roku jest. W zeszłym roku jeszcze dostałem. Nie wiem, czy w tym roku jeszcze./ To jest dużo z ich strony"28.

Oczywiście to nie sam czas łagodzi urazy, nie sam jego upływ zmienia te nastawienia, ale także klimat polityczny, w którym pamiętanie doświadczeń wojennych i obozowych się odbywa. Odszkodowania - mimo, że często krytykowane jako niewystarczające - grają tu niemałą rolę. Ale chyba większą wszelkie formy osobistych kontaktów z „dobrymi” Niemcami po wojnie. Powyższy fragment jest tu bardzo reprezentatywny dla takiej właśnie zmiany.

Dla tego, jaki stosunek wobec Niemców manifestują ocaleni z kacetów, nie jest także obojętne, co o Niemcach się mówi, jaka narracja o nich jest dominująca. Warto może przypomnieć, że w pierwszych latach powojennych chętnie łamano reguły polskiej gramatyki, by nie było wątpliwości, że "niemcy” to zbrodniarze, zasługujący jedynie na uczucie nienawiści. Ta mała litera, to nie była przy tym jedynie spontaniczna reakcja na doświadczenia wojny, ale po części także odgórne rozstrzygnięcie, z kim nie należy się zadawać (a w domyśle: z kim należy).

Jeszcze jeden krótki i bardziej "polityczny” passus potwierdzający ewolucję postrzegania Niemców:

„Teraz już nie [czuję nienawiści - PF]. Pamiętam jak Gomułka się całował w telewizji, to nie mogłem... Przecież Polacy byli niczym u Niemców. A jeszcze w obozie..." 29 .

Ciekawe, że niechęć do Niemców objawia się tu jednocześnie z niechęcią do Gomułki i dystansem do świata, który on reprezentował. Nie

28 Relacja Zygmunta K. nagrana w projekcie MSDP, sygnatura w Archiwum Historii Mówionej Ośrodka KARTA: MSDP_101; w Archiwum Mauthausen w Wiedniu: OH/ $\mathrm{ZP} 1 / 559$.

29 Relacja Mirosława C. nagrana w projekcie MSDP, sygnatura w Archiwum Historii Mówionej Ośrodka KARTA: MSDP_162; w Archiwum Mauthausen w Wiedniu: OH/ $\mathrm{ZP} 1 / 792$. 
wiem dokładnie, z kim Gomułka wymieniał wtedy pocałunki przed telewizyjnymi kamerami. Możemy się tylko domyślać, że z przywódcą NRD, Walterem Ulbrichtem. Dopełnieniem tamtego obrazu może być jeszcze taki fragment tej samej relacji:

„Nigdzie nie należałem. Nic. Ani do partii, ani/ Chcieli mnie niesamowicie. W zakładzie. - Mirku, chodź, tego...- Nie! Nie będę. Zapiszcie mnie, ale nie będe płacit. No to nie. Do niczego nie należałem. Do związków zawodowych [tak - PF], bo musiałem. Bo to były związki. Bo to było tak, że po wojnie, no/ Muszę wam powiedzieć: Po wojnie, jakżem pracował, to żem był prawy. A teraz więcej lewy. [śmiech]. No bo też mi się niektóre rzeczy nie podobały"30.

I tu nie jest zaskoczeniem, że żaden z tych fragmentów - ani żaden im podobny - nie znalazł się w analizowanych „oświadczeniach” złożonych dla Muzeum Auschwitz-Birkenau. I to nawet w tych, które mają formę otwartą, narracyjną i - w porównaniu z innymi dokumentami z tej kolekcji znacznie bardziej - przypominają swobodne relacje autobiograficzne.

Nie sposób budować mocnych uogólnień na garści przykładów. Zwłaszcza - jak te wszystkie tutaj - wyjętych z wielkich i bardzo zróżnicowanych zbiorów. Nie to było celem tego krótkiego przeglądu. Chodziło tylko o jakieś wstępne, jedynie znakowe, rozeznanie podobieństw i różnic między dwoma typami źródeł. Wydaje się, że bardzo podobnymi, bo wywołanymi po latach, narracyjnymi, biograficznymi (choć w różnym stopniu), całkowicie zapośredniczonymi przez ludzką pamięć i zapomnienie, także przez narrację. Mnie to porównanie umacnia w przekonaniu, że tam, gdzie to możliwe, warto zachęcać tę pamięć do podejmowania swobodnych, nieskrępowanych wędrówek. Wówczas opowieść, która na tej pamięci jest fundowana, ma szansę popłynąć szerszym i głębszym strumieniem. Z takiego łatwiej odławiać nie tylko przeszłe doświadczenia, ale też nadawane im sensy. I to, jak się zdaje, bez żadnej straty - a bywa, że z zyskiem - dla historycznych faktów.

Ale ten krótki, bardzo selektywny przegląd pokazuje chyba coś jeszcze ważniejszego. To mianowicie, że warto porównywać te źródła, dokonywać

30 Ibidem. 
ich szczegółowej analizy. Także re-analizy. Z tego porównania mamy bowiem szansę dowiedzieć się czegoś nowego, dodatkowego o przeszłości. A także - i zapewne nie mniej - o teraźniejszości powstania tych źródeł, która też należy już do przeszłości - w niej jest osadzona i coś o niej mówi.

Że do przeszłości żadnego bezpośredniego wglądu nie mamy - to wiedza nienowa, raczej truizm czy banał. Czasem jednak - może przez swą oczywistość i 'przezroczystość' - jakby zapominany. Tu mogliśmy sobie tę wiedzę odświeżyć. I co chyba ważne - nie tylko „filozofując”, ale też sięgając do kilku konkretnych i dość chyba wyrazistych przykładów. To właściwie tylko przykłady takich przykładów, ale już po tej ich garści widać, że historia mówiona ma tu coś do zaproponowania. Ja mam przekonanie, że oferuje całkiem sporo, jeśli zainteresowani jesteśmy podejmowaniem prób rozpoznawania i rozumienia zawiłych relacji między historycznymi faktami, ludzkimi doświadczeniami, pamięcią i - dostępną nam na końcu - narracją o nich. 
One of the main objections against oral history interviews is their retrospective character - the distance from the time of events which are covered by the interviews. While it is not the distance itself that is the issue but its deforming potential: the susceptibility of memory to later, in relation to the discussed events, influences. Another issue is the influence of an interview situation itself, relation between the person documenting interview / the researcher and the so-called witness to history.

The text starts with those theoretical and methodological questions and considers them on the example of concrete, empirical material. The material is the so-called representations of former Auschwitz prisoners gathered through decades by the Auschwitz-Birkenau State Museum as well as biographic and narrative interviews with the same people recorded in years 2002-2003 for the Mauthausen Survivors Documentation Project and archived in the Oral History Archive of the Karta Center and the History Meeting House.

Thorough comparison of both accounts from the same person delivered orally at a different time, place and in a different context (biographic, social, historical) conducted by different institutions and on the basis of different methodologies allows one to analyze the influence of different contexts on the content of the stories told. The effect of those analyses is a new picture of dependencies between the memory of experience of there and then and the entanglement of stories of this experience with the here and now reality. This picture seems quite distant both from naive realism as well as - although today it may seem quite surprising - from extreme constructivism. Analyzed accounts prove to be quite stable and resistant to the lapse of time as well as the current context of an interview situation. In this last regard, on the basis of analyzed sources, one can formulate some methodological postulates related to its impact.
Piotr

Filipkowski

On the accounts of former prisoners of Nazi concentration camps in the context of time, space and circumstances in which they were recorded (or on the benefits of oral history) 